\title{
POSITIVE MENTAL HEALTH SURVEILLANCE INDICATOR FRAMEWORK QUICK STATS, YOUTH (12 TO 17 YEARS OF AGE), CANADA, 2017 EDITION
}

Tweet this article

Positive mental health is a state of well-being that allows people to feel, think and act in ways that enhance the ability to enjoy life and deal with challenges. ${ }^{1}$ The Positive Mental Health Surveillance Indicator Framework ("the Framework") provides comprehensive, high quality information on the outcomes and risk and protective factors associated with positive mental health across four domains (individual, family, community and society), to support research and policy development. The release of the Framework for youth aged 12 to 17 years is the second in a series; the Framework for adults aged 18 years and older was released in early $2016 .^{2}$ The Framework was developed in consultation with stakeholders working in mental health surveillance, programs and policy. The details of the development of the Frameworks across the life course, for adults, youth and children, can be found in the paper "Monitoring positive mental health and its determinants." ${ }^{3}$ More data on positive mental health can be found online using the Public Health Agency of Canada's interactive data tool, "Infobase."

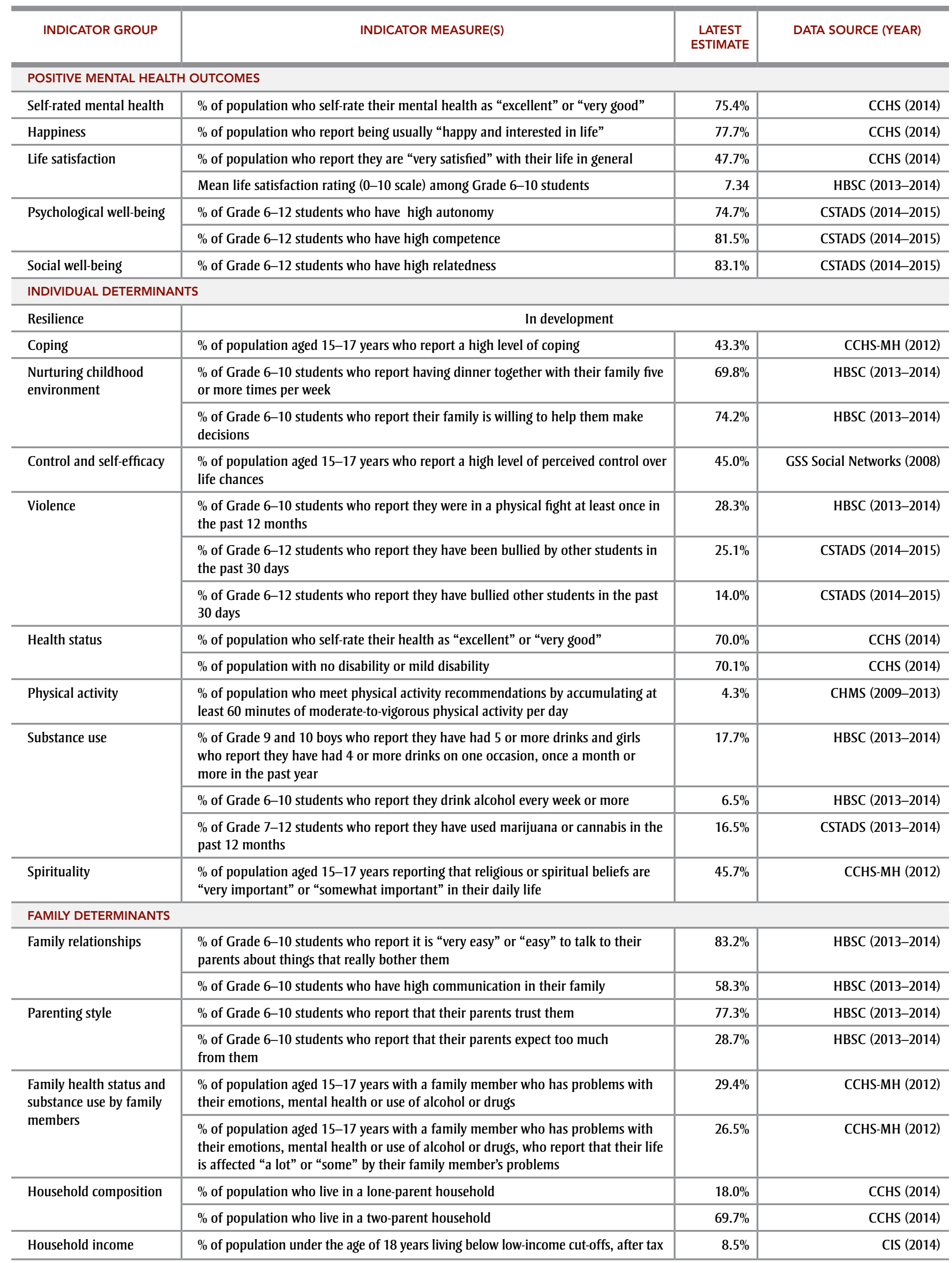




\begin{tabular}{|c|c|c|c|}
\hline INDICATOR GROUP & INDICATOR MEASURE(S) & $\begin{array}{l}\text { LATEST } \\
\text { ESTIMATE }\end{array}$ & DATA SOURCE (YEAR) \\
\hline Community involvement & $\%$ of Grade $6-10$ students who are involved in at least one club or organization & $88.9 \%$ & HBSC (2013-2014) \\
\hline Social networks & $\begin{array}{l}\% \text { of Grade 6-10 students who report they can count on their friends when things } \\
\text { go wrong }\end{array}$ & $74.3 \%$ & HBSC (2013-2014) \\
\hline Social support & $\%$ of population aged $15-17$ years with a high level of perceived social support & $95.4 \%$ & CCHS-MH (2012) \\
\hline School environment & $\%$ of Grade 6-10 students who report they feel they belong at their school & $63.2 \%$ & HBSC (2013-2014) \\
\hline $\begin{array}{l}\text { Neighbourhood social } \\
\text { environment }\end{array}$ & $\begin{array}{l}\% \text { of Grade } 6-10 \text { students who report they can trust people in the area where } \\
\text { they live }\end{array}$ & $60.2 \%$ & HBSC (2013-2014) \\
\hline $\begin{array}{l}\text { Neighbourhood built } \\
\text { environment }\end{array}$ & $\begin{array}{l}\% \text { of Grade } 6-10 \text { students who report there are places such as recreation centres, } \\
\text { parks and shopping centres to spend free time in the area where they live }\end{array}$ & $74.2 \%$ & HBSC (2013-2014) \\
\hline \multicolumn{4}{|c|}{ SOCIETAL/STRUCTURAL DETERMINANTS } \\
\hline Inequality & \multicolumn{3}{|l|}{ In development } \\
\hline $\begin{array}{l}\text { Discrimination and } \\
\text { stigma }\end{array}$ & $\begin{array}{l}\% \text { of population who experienced unfair treatment at least once in the past year } \\
\text { based on characteristics such as gender, race, age or appearance }\end{array}$ & $39.1 \%$ & $\begin{array}{r}\text { CCHS (2013) Discrimination } \\
\text { Rapid Response }\end{array}$ \\
\hline
\end{tabular}

Abbreviations: CCHS, Canadian Community Health Survey; CCHS-MH, Canadian Community Health Survey—Mental Health; CHMS, Canadian Health Measures Survey; CIS, Canadian Income Survey; CSTADS, Canadian Student Tobacco, Alcohol and Drugss Survey; GSS, General Social Survey; HBSC, Health Behaviours in School-Aged Children.

Note: "In development" refers to measures that are under development either because a data source is currently not available or because more research has to be done to identify a promising measure and data source.

Suggested citation: Centre for Chronic Disease Prevention. Positive Mental Health Surveillance Indicator Framework: Quick Stats, youth (12 to 17 years of age), Canada, 2017 Edition. Health Promot Chronic Dis Prev Can. 2017;37(4):131-2.

\section{References}

1. Public Health Agency of Canada. Mental health promotion: promoting mental health means promoting the best of ourselves [Internet]. Ottawa (ON): Public Health Agency of Canada; [modified 2014 May 6; cited 2017 Feb 8]. Available from: http://www .phac-aspc.gc.ca/mh-sm/mhp-psm/index-eng.php

2. Centre for Chronic Disease Prevention. Positive Mental Health Surveillance Indicator Framework: Quick Stats, adults (18 years of age and older), Canada, 2016 Edition. Health Promot Chronic Dis Prev Can. 2016;36(1):11-2.

3. Orpana H, Vachon J, Dykxhoorn J, McRae L, Jayaraman G. Monitoring positive mental health and its determinants: the development of the Positive Mental Health Surveillance Indicator Framework. Health Promot Chronic Dis Prev Can. 2016;36(1):1-10.

4. Public Health Agency of Canada. Public Health Infobase: Positive Mental Health Surveillance Indicator Framework [Internet]. Ottawa (ON): Public Health Agency of Canada; [modified 2016 Sept 19]. Available from: http://infobase.phac-aspc.gc.ca/positive -mental-health/index-en.aspx? 